\title{
Radionuclides in the Loire river estuary (France): Sources, transport and fate
}

\author{
F. Siclet, M. Guesmia, P. Ciffroy, J.L. Reyss ${ }^{1}$, M. Fontugne ${ }^{1}$, G. Lepetit ${ }^{2}$, \\ P. Jean-Baptiste ${ }^{1}$ and L. Drouadaine
}

\author{
EDF R\&D, Département Laboratoire National d'Hydraulique et Environnement, \\ 6 quai Watier, 78401 Chatou, France \\ 'Laboratoire des Sciences du Climat et de l'Environnement, UMR 1572 du CEA/CNRS, \\ Domaine du CNRS, 91198 Gif-sur-Yvette cedex, France \\ ${ }^{2}$ Département Analyse, Surveillance, Environnement, Service Radioanalyse, \\ Chimie et Environnement, CEAVDAM lle de France, BP. 12, 91680 Bruyères-le-Châtel, France
}

\begin{abstract}
Anthropogenic radionuclide inputs in the Loire estuary (French Atlantic coast) consist of radioactive releases from 14 nuclear reactors located along the Loire river basin, and of fallout from nuclear weapon tests and from the Tchernobyl accident. To estimate to what extent radionuclides associated with sediment accumulate in the estuary, three complementary approaches were used: field surveys, laboratory experiments and numerical modelling. Sampling of bottom sediments, water and suspended solids was carried out at 8 different dates over a 15 month-period . Analysis covered ${ }^{14} \mathrm{C},{ }^{90} \mathrm{Sr},{ }^{3} \mathrm{H}$, the naturally occurring gamma-emitters (uranium and thorium decay chains, ${ }^{7} \mathrm{Be}$ and ${ }^{40} \mathrm{~K}$ ), and the artificial gamma emitters (mainly cobalt and cesium isotopes). To gain information on the contamination history of the estuary, sediment cores were also collected at different locations inside and outside the estuarine zone. Processes of radionuclide transport and exchange between dissolved and particulate phases were included in a previously developed estuary specific 2D-hydrodynamic model. Equations of sorption and desorption kinetics were derived from laboratory experiments conducted at different salinities. Simulations carried out for two river discharge conditions (low summer flow, high winter flow) allowed to follow radionuclide desorption in the estuary. For long term simulations, a simplified model was developed. It provided estimates of the amount of radionuclides expelled out of the estuary under dissolved and particulate forms, of the transit time for both forms and of the variations in radionuclides concentrations in the fluid mud. Based on computed results and observations, contributions from different origins (natural, military, industrial, marine, continental) to the inventory of radioactivity in the estuary are presented.
\end{abstract}

\section{INTRODUCTION}

The Loire river watershed is the greatest in France with a drainage area of about $120000 \mathrm{~km} 2$ representing one fifth of France surface area. With a mean annual discharge of $850 \mathrm{~m} 3 / \mathrm{s}$, it is one of the main riverine input to the Atlantic Ocean, in western Europe and stands as the most « nuclearized » river basin with 14 nuclear power plants operating along the Loire river and its tributaries. The Loire river estuary exhibits the typical features of a macrotidal estuary: the mixing of freshwater with seawater creates a salinity and density gradient which is responsible for the formation of the turbidity maximum. With up to 1 million tons of suspended sediment trapped in the estuary, the Loire river estuary was identified as an important radionuclide accumulation zone and included in the "Loire and estuary radioecology » program, a global study of radionuclides transfer in the Loire river basin.

To evaluate the residence times and accumulation of contaminant, it is essential to distinguish between dissolved and particulate forms since dissolved radionuclides are exported more rapidly to the ocean than particulate forms which undergo numerous episodes of deposition and resuspension. Although there is a general understanding of individual processes that affect the fate of particle-reactive contaminants in estuarine systems, it has been very difficult to quantify the partitioning between water and particles because of the complex suite of physical and biogeochemical interactions that take place when fresh water mixes with seawater in conjunction with the formation of turbidity maximum. The use of numerical modeling in combination with field surveys and laboratory experiments was the approach chosen to help in the quantification of accumulation in estuary and net exchange between rivers and the ocean. 


\section{SEASONAL INVESTIGATIONS OF RADIOACTIVITY IN THE ESTUARINE TURBIDITY MAXIMUM}

Sampling of bottom sediments, water and suspended solids was carried out at 8 different dates over a 15 month-period. The survey strategy was composed to include various tide conditions from neap tide to spring tide at low and high river flows (Table1). Different depths in the water column were sampled, surface, intermediate and bottom. A total of 28 large water samples (300 to 2000 liters) were collected, along with 12 fluid mud samples and 11 bottom sediment samples. Analysis covered ${ }^{14} \mathrm{C}$ (dissolved and associated to particulate organic matter), ${ }^{90} \mathrm{Sr}$ (dissolved and particulate), ${ }^{3} \mathrm{H}$ (tritiated water and organic bound tritium), the naturally occurring gamma-emitters (uranium and thorium decay chains, ${ }^{7} \mathrm{Be}$ and ${ }^{40} \mathrm{~K}$ ), and the artificial gamma emitters (mainly cobalt and cesium isotopes) in the dissolved and particulate fractions.
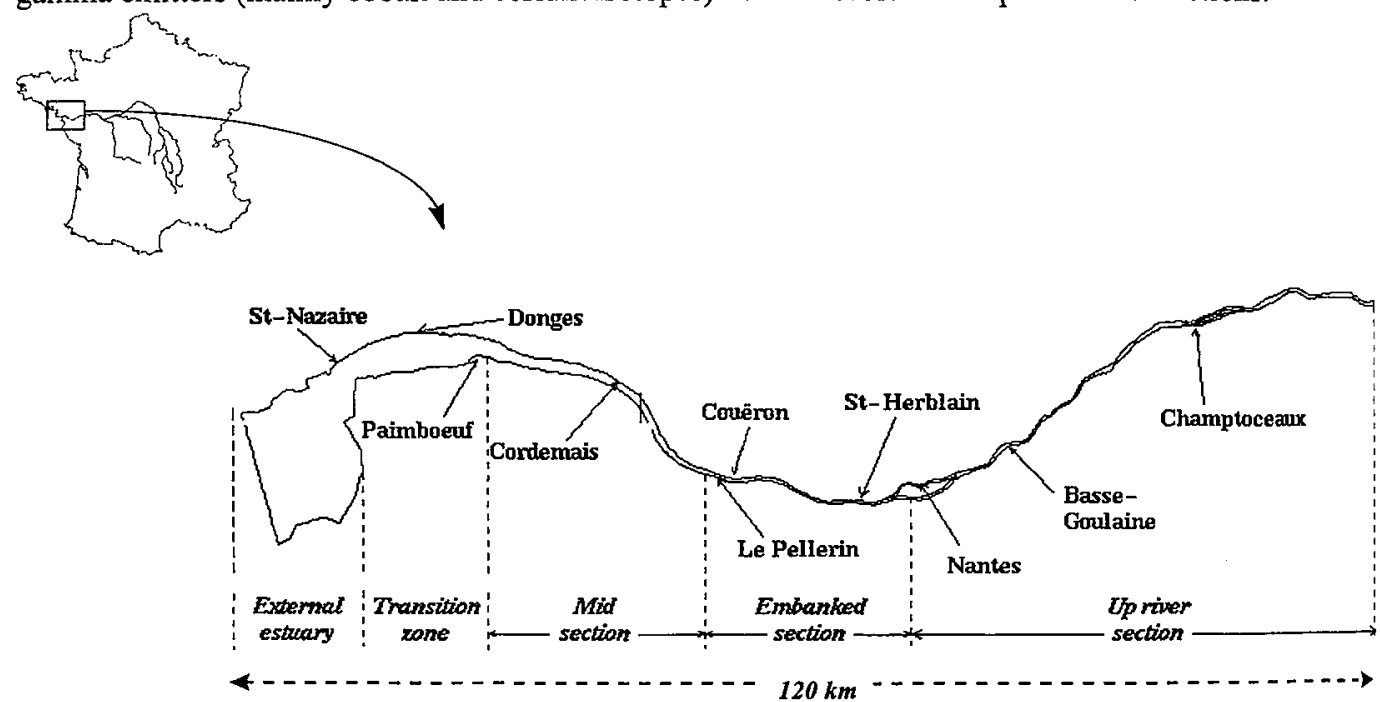

Figure $1:$ Location of study area

Table 1 - Sampling strategy

\begin{tabular}{|c|c|c|c|c|l|}
\hline $\begin{array}{c}\text { Survey } \\
\text { number }\end{array}$ & Date & $\begin{array}{c}\text { Tidal } \\
\text { coef. }\end{array}$ & $\begin{array}{c}\text { Loire river } \\
\text { flow rate } \\
\left(\mathbf{m}^{\mathbf{3}} \mathbf{s}^{-\mathbf{l}} \mathbf{)}\right.\end{array}$ & $\begin{array}{c}\text { Position of the } \\
\text { turbidity } \\
\text { maximum }\end{array}$ & \multicolumn{1}{|c|}{ Sampling type } \\
\hline 1 & $03 / 07 / 1998$ & 41 & 292 & Cordemais & vertical profile at high tide \\
\hline 2 & $08 / 07 / 1998$ & 71 & 270 & Cordemais & $\begin{array}{l}\text { variability over a tidal cycle : vertical profile at } \\
\text { high tide, ebb tide, low tide, flow tide, and nert } \\
\text { high tide }\end{array}$ \\
\hline 3 & $15 / 09 / 1998$ & 47 & 225 & Le Pellerin & vertical profile at high tide \\
\hline 4 & $05 / 02 / 1999$ & 78 & 1310 & Donges & $\begin{array}{l}\text { variability over a tidal cycle : vertical profile at } \\
\text { high tide, ebb tide, low tide, flow tide, and nexl } \\
\text { high tide }\end{array}$ \\
\hline 5 & $25 / 02 / 1999$ & 51 & 3070 & St-Nazaire & transect on the ebb tide \\
\hline 6 & $17 / 05 / 1999$ & 107 & 663 & Cordemais & vertical profile on the flood tide \\
\hline 7 & $12 / 07 / 1999$ & 93 & 267 & Le Pellerin & vertical profile on the flood tide \\
\hline 8 & $28 / 09 / 1999$ & 101 & 354 & Le Pellerin & vertical profile on the flood tide \\
\hline
\end{tabular}

A seawater sample was collected along the Atlantic coast near Le Croisic to serve as a reference Results are presented in more details in [ 1] for ${ }^{137} \mathrm{Cs}$ and ${ }^{90} \mathrm{Sr}$ and [ 2] for ${ }^{14} \mathrm{C}$. 


\subsection{Particle associated radioactivity}

Natural radioactivity in SPM and sediment was dominated by ${ }^{40} \mathrm{~K}$ (above $600 \mathrm{~Bq} / \mathrm{kg}$ ) followed by ${ }^{210} \mathrm{~Pb}$ $(150 \mathrm{~Bq} / \mathrm{kg}),{ }^{238} \mathrm{U}$ and ${ }^{232} \mathrm{Th}$ families $(50 \mathrm{~Bq} / \mathrm{kg})$ and ${ }^{7} \mathrm{Be}(30 \mathrm{~Bq} / \mathrm{kg})$. Anthropogenic radionuclides concentrations range from $10 \mathrm{~Bq} / \mathrm{kg}$ for ${ }^{137} \mathrm{Cs}$ to below detection limit $(0,1 \mathrm{~Bq} / \mathrm{kg})$ : the order of abundance was ${ }^{137} \mathrm{Cs}>{ }^{14} \mathrm{C}>\mathrm{OBT}$ (organic bound tritium) $>{ }^{60} \mathrm{Co}>{ }^{134} \mathrm{Cs},{ }^{110 \mathrm{~m}} \mathrm{Ag},{ }^{90} \mathrm{Sr}$. Radionuclides, such as ${ }^{83} \mathrm{Co},{ }^{54} \mathrm{Mn},{ }^{131} \mathrm{I}$, although present in nuclear power plant discharges, were always below the detection limit in the estuarine particles.

Comparison with radionuclide concentrations in the Loire river was possible using the CRESCENDO model results [ 3]. The CRESCENDO model calculates concentrations in the dissolved, particulate and sedimentary forms of radionuclides released by nuclear power plants. The results obtained in Montjean-sur-Loire, which is the limit of tidal incursion, were used for comparison. Observed 60Co and $110 \mathrm{mAg}$ concentrations lay within one order of magnitude of the calculated Loire inputs (Figure 2), whereas observed $137 \mathrm{Cs}$ and $90 \mathrm{Sr}$ concentrations were respectively 20 and 100 times higher than the calculated values, demonstrating that the main origin for these two radionuclides was still weapon test fallout.
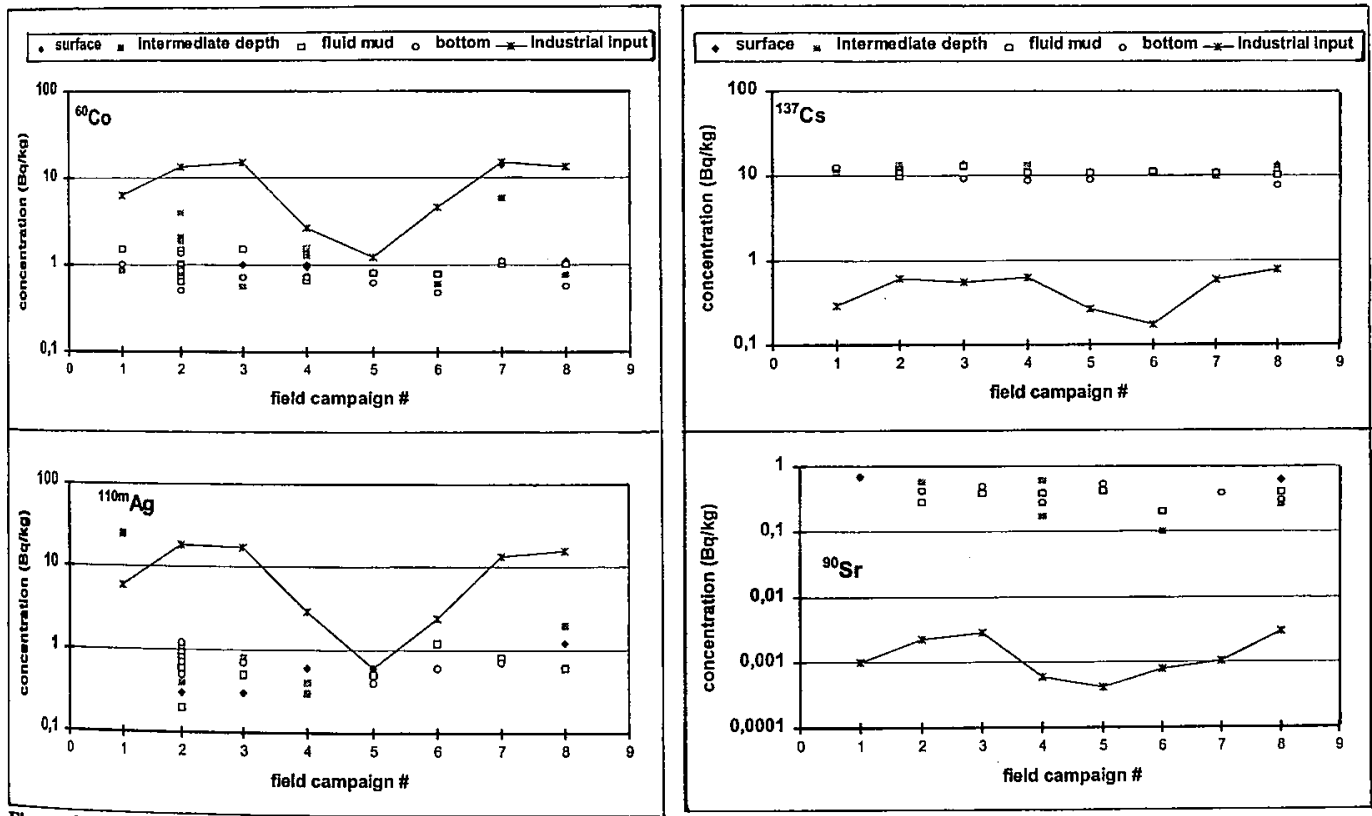

Figure 2 - Comparison between radionuclide particulate concentrations in the turbidity maximum and in Loire input from industrial releases

\subsection{Dissolved radioactivity}

Tritium was the most abundant radionuclide with a mean concentration of $7,6 \mathrm{~Bq} / 1$, closely followed by ${ }^{40} \mathrm{~K}(2,7 \mathrm{~Bq} / \mathrm{l}) .{ }^{14} \mathrm{C},{ }^{90} \mathrm{Sr}$ and ${ }^{7} \mathrm{Be}$ were lower by three orders of magnitude and ranged between 3 and 5 $\mathrm{mBq} / \mathrm{l}$. They were followed by ${ }^{137} \mathrm{Cs}(0,4 \mathrm{mBq} / \mathrm{l}) .{ }^{60} \mathrm{Co}$ was only detected in a few samples $(0,01 \mathrm{mBq} / \mathrm{l})$; ${ }^{131} \mathrm{I}$ was more frequent with an average of $0,05 \mathrm{mBq} / \mathrm{l}$. 

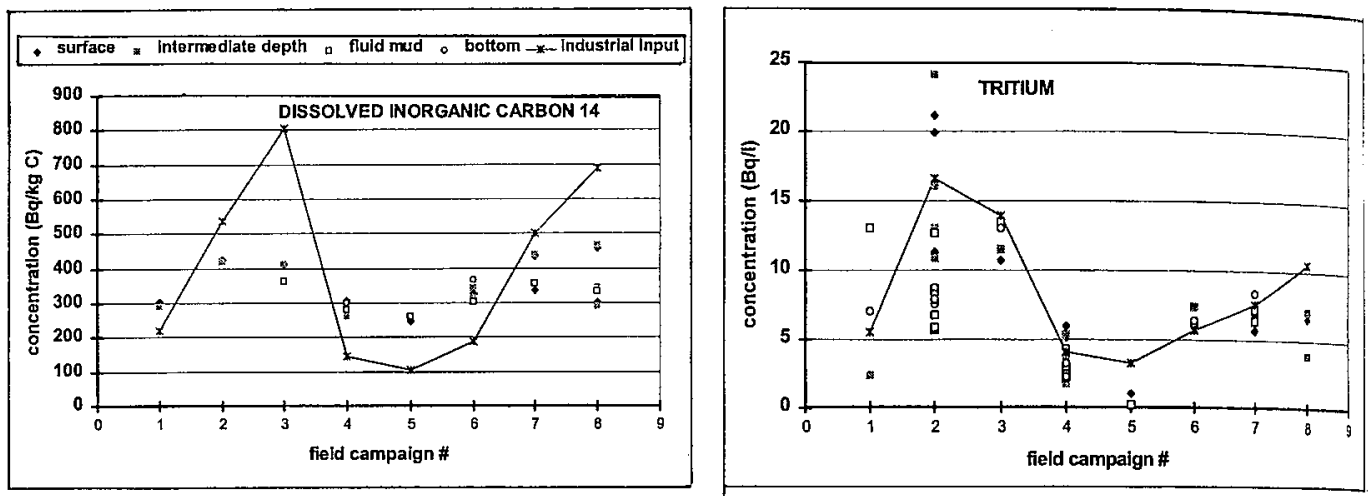

Figure $3 \cdot{ }^{14} \mathrm{C}$ and ${ }^{3} \mathrm{H}$ concentrations in the turbidity maximum and in Loire input from industrial releases

Variations in tritium concentrations coincided with calculated Loire input (Figure 3). The same trend was observed for ${ }^{14} \mathrm{C}$ but variations in the Loire estuary were smaller than in the Loire input. This could be due to an overestimation of ${ }^{14} \mathrm{C}$ industrial input since the CRESCENDO model considers ${ }^{14} \mathrm{C}$ as a conservative dissolved tracer. The presence of ${ }^{14} \mathrm{C}$ from natural sources at a concentration averaging 250 $\mathrm{Bq} / \mathrm{kg} \mathrm{C}$ also explains the elevated base level. Dissolved ${ }^{137} \mathrm{Cs}$ concentrations increased linearly with salinity as could be expected from known behavior of cesium. However, ${ }^{137} \mathrm{Cs}$ particulate concentrations remained very stable along the salinity range.

\section{MODELLING RADIONUCLIDE TRANSFER IN THE ESTUARY}

To help in the understanding of radionuclide sorption and desorption processes in the estuarine environment where salinity and SPM concentrations are changing very rapidly, a multivariate transport model was developed, based on an existing hydrodynamic model of the Loire estuary. It represents tidal propagation, salt intrusion, transport of radionuclide and suspended sediment, sedimentation and erosion, as well as radionuclide exchange kinetics between dissolved and particulate forms. Laboratory experiments of the sorption and desorption kinetics of $\mathrm{Co}, \mathrm{Mn}, \mathrm{Cs}, \mathrm{Ag}$, and $\mathrm{Sr}$ were conducted with Loire river and Loire estuary waters. Based on their results, a two-step kinetic model describing the interactions between radionuclides and particles under a salinity gradient was developed and calibrated [ 4]. It was included in the hydrodynamic and sedimentary model.
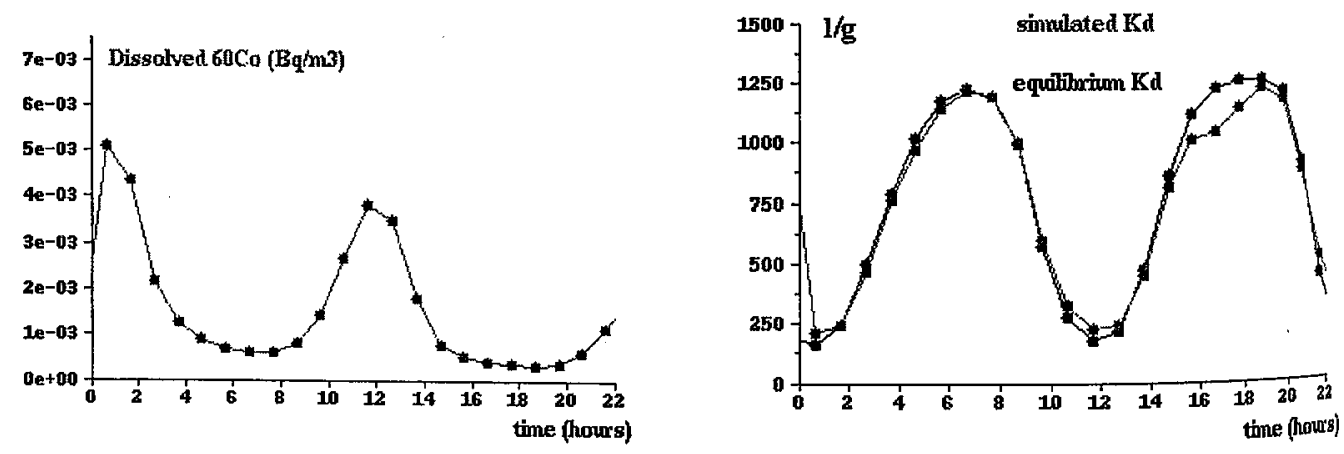

Figure 4 - Simulation of $60 \mathrm{Co}$ behavior during two tides (simulation starts at high tide). Comparison with experimental equilibrium $\mathrm{Kd}$

The objective of the simulations was to follow over a few tides the sorption and desorption processes [5]. As an initial condition, radionuclides were considered to be solely associated with particles. Results 
showed the same general trend for cesium, cobalt and silver. Desorption occurred immediately until the experimental $\mathrm{Kd}$ at a given salinity was reached (one hour after the beginning of the simulation) (Figure 4). Afterwards, dissolved and particulate forms respect the fluctuation of the Kd according to salinity. It thus appeared that taking into account exchange kinetics was not necessary and that equilibrium $\mathrm{Kd}$ as a function of salinity correctly represented partitioning between dissolved and particulate forms.

This detailed spatial hydro-sedimentary model could not be used for long term simulations because of numerical problems. For this purpose, a box-type model was developed (Figure 5) which considers that contaminant entering the estuarine compartment is instantly mixed with the compartment water and exchange with solids according to $\mathrm{Kd}$. The concentration in the outflow to the ocean is the same as in the compartment, the net water flux to the ocean is equal to the river flow input, the rate of removal of particles and particle associated radionuclides is calculated by a function taking into account the Loire river flow during the 30 previous days. This relation was established by Ciffroy [6] using ${ }^{7} \mathrm{Be}$ to estimate particles age. The removal rate varied between 0,002 day $^{-1}$ at low river flow and 0,02 at high flow. The input data from the Loire river are the results of the CRESCENDO model (river flow, SPM concentrations, dissolved and particulate radionuclide concentrations) which only takes into account the industrial releases of radionuclides.

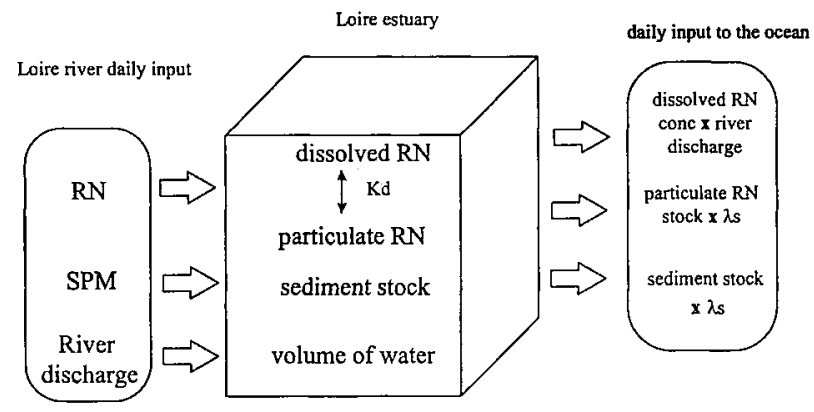

Figure 5 - Loire estuary box-model. $\lambda s$ is the apparent rate constant of sediment removal from the estuary

Model parameters values were taken from the results of the detailed spatial model and the laboratory experiments and checked with the field surveys data. In a first step the box-model dissolved contaminant transfer was compared to tritium measurements. Then it was checked for particulate contaminant against ${ }^{6} \mathrm{Co}$ field data. To improve the fit between predicted and observed values, from this study as well as from other field studies of the solid load in the estuary [7], it was necessary to include in the model the in situ production of particles, through processes such as flocculation. The average in situ production rate was derived from Negrel [ 8] who estimated that half of the particles exported by the Loire river estuary were produced in situ. The resulting average sediment stock in the estuary was then 930000 tons which is consistent with other published data. Export to the ocean varied between an average value of 2800 tons/day for river flows lower than the module, to 10000 tons/day for river flows of $2000 \mathrm{~m} 3 / \mathrm{s}$. The sediment mass was completely exported to the sea at river flow above $5000 \mathrm{~m} 3 / \mathrm{s}$. 

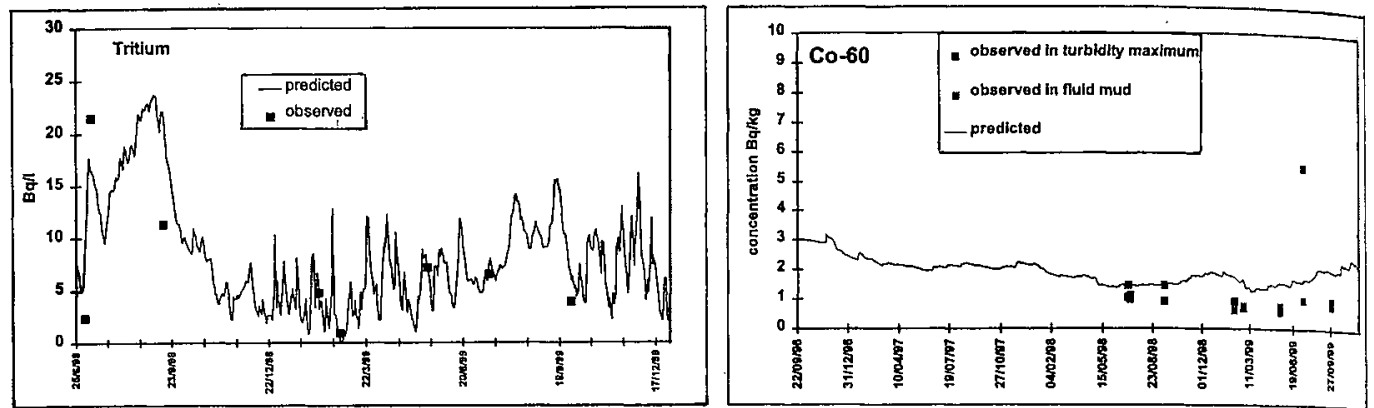

Figure 6 - Comparison between observed and box-model predicted radionuclides concentrations in the turbidity maximum
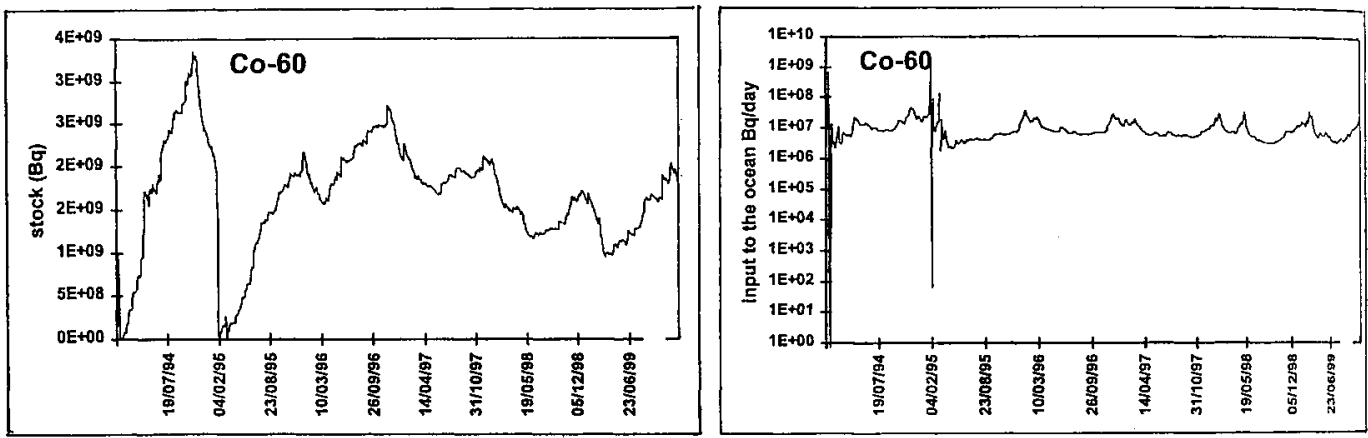

Figure 7 - Evolution of ${ }^{60}$ Co estuarine stock and export to the ocean.

Once the model was calibrated (Figure 6), it was used to evaluate the radionuclide stock in the estuary and the flux to the ocean over a six-year period (Figure 7). Average ${ }^{60} \mathrm{Co}$ stock in the estuary was $1,7 \mathrm{GBq}$, it represents $37 \%$ of the total annual power plants radioactive releases. Export to the ocean amounted to approximately $4 \mathrm{MBq}$ / day and could reach $1 \mathrm{GBq}$ /day at very high river flows. The average residence time of $60 \mathrm{Co}$ in the estuary was 133 days. For tritium, the average stock in the estuary was 2,2 TBq. When compared to NPP tritium discharge of $0,39 \mathrm{TBq} / \mathrm{day}$, it allowed to calculate an average estuarine residence time for conservative dissolved pollutants of 5,4 days.

Similar calculations were conducted for ${ }^{110 \mathrm{~m}} \mathrm{Ag}$ for which NPP radioactive releases represent the only source. For radionuclides with several origins, the concentrations in the estuary resulting from the radioactive releases were calculated with the box-model and compared to the observed concentrations to calculate the contribution of the industrial source.

\section{CONCLUSIONS}

Radionuclide accumulation in the Loire river estuary sediment is controlled by the sediment turnover rate Although the total sediment mass is exported only for very high river flows (occuring every 5 year on average), particles residence times are much shorter (222 days) and particulate radionuclide residence times are even smaller due to desorption and radioactive decay (133 days for ${ }^{60} \mathrm{Co}$ ). Natural radionuclides represented the largest contribution to the radioactivity present in the sediment with an average stock of $\sim$ TBq. Nuclear power plants effluents are the only contributors to ${ }^{60} \mathrm{Co}$ and ${ }^{110 \mathrm{~m}} \mathrm{Ag}$ inventories of $\sim 2 \mathrm{GBq}$. They contribute to $5 \%$ of the ${ }^{137} \mathrm{Cs}$ inventory (total $\sim 9 \mathrm{GBq}$ ), the main source being fallout from nuclear weapon tests. Contribution from Tchernobyl is unsignificant. Particulate ${ }^{14} \mathrm{C}$ inventory of $\sim 7 \mathrm{GBq}$ is due to natural sources $(76 \%)$ and fallout; industrial releases only contribute to the dissolved ${ }^{14} \mathrm{C}$. Sediment anthropogenic radioactivity has been decreasing since the beginning of the eighties and should continue to decrease with the slow decay of fallout radionuclides. 


\section{References}

[1] Reyss J.L., Le Petit G. and Siclet F., $~ "{ }^{137} \mathrm{Cs}$ and ${ }^{90} \mathrm{Sr}$ in the estuarine turbidity maximum of the Loire river $\%$, Ecorad 2001, Aix-en-Provence, Sept 3-7, 2001.

[2] Fontugne M., Sadouni N. and Saliot A., $"{ }^{14} \mathrm{C}$ activity in water and identified organic matter in the Loire estuary (France) », Ecorad 2001, Aix-en-Provence, Sept 3-7, 2001.

[3] Siclet F., Luck M., Le Dortz J.G., Damois C., Ciffroy P., Hendrickx F. and Courivaud J.R., «Radionuclides concentrations in the Loire river system resulting from routine discharges of five nuclear power plants. Assessment of dose to man ", Ecorad 2001, Aix-en-Provence, Sept 3-7, 2001.

[4] Ciffroy P., Garnier J.M. and Benhyahya L., "Adsorption/desorption kinetics of Co, Mn, Cs, Fe, Ag, Zn and Cd in the Loire and the macro-tidal Loire estuary: experimental and modelling approaches "», Ecorad 2001, Aix-en-Provence, Sept 3-7, 2001.

[5] Guesmia M., Reyss J.L. and Cheviet C. « Hydrodynamics and suspended matter motion in the Loire estuary (France) : modelling of ${ }^{60}$ Co concentrations $»$, Ecorad 2001, Aix-en-Provence, Sept 3-7, 2001.

[6] Ciffroy P., Reyss J.L.and Siclet F., «Determination of suspended particles age in the turbidity maximum of the Loire estuary by ${ }^{7} \mathrm{Be}$ analysis $»$, Ecorad 2001, Aix-en-Provence, Sept 3-7, 2001.

[7] CSEEL, Etude de la masse turbide de l'estuaire interne de la Loire, (Comité Scientifique pour l'Environnement de l'Estuaire de la Loire, Nantes, 1983). 